\title{
Dialogues on the body image of the elderly: community empowerment strategy promoting health
}

\author{
Diálogos sobre a imagem corporal de idosos: estratégia de empoderamento comunitário \\ promotor da saúde
}

Raquel Cristina Luis Mincoff ${ }^{1}$, Poliana Ávila Silva ${ }^{1}$, Mariana Pissioli Lourenço ${ }^{1}$, Iara Sescon Nogueira ${ }^{1}$, Vanessa Denardi Antoniassi Baldissera ${ }^{1}$

Objective: to understand dialogues on body image with the elderly in Primary Health Care. Methods: action research, developed with 15 elderly participants of a coexistence group. The data were obtained by the techniques of photo-elucidation and emancipatory workshop, later submitted to the Descending Hierarchical Classification using the IRaMuTeQ ${ }^{\circledR}$ software. Paulo Freire's theoretical-analytical framework was followed. Results: aging reflected a combination between the representative changes of reality, with distorted visions and related to the jovial stereotype. Collective actions signaled that the elderly recognized the changes caused by old age, but these did not prevent them from participating in the group independent of their self-esteem, strengthening the process of empowerment. Conclusion: the concern of beauty and appearance as body representations imposed by society was highlighted, even with the natural marks of aging, the elderly feel satisfied with their body image. Descriptors: Aged; Health of the Elderly; Health Promotion.

Objetivo: compreender diálogos sobre imagem corporal junto aos idosos na Atenção Primária à Saúde. Métodos: pesquisa-ação, desenvolvida com 15 idosos participantes de um grupo de convivência. Os dados foram obtidos pelas técnicas de foto-elucidação e oficina emancipatória, posteriormente submetidos à Classificação Hierárquica Descendente utilizando o software $I R a M u T e Q{ }^{\circledR}$. Seguiu-se o referencial teórico-analítico de Paulo Freire. Resultados: o envelhecimento refletiu uma combinação entre as mudanças representativas da realidade, com visões distorcidas e relacionadas ao estereótipo jovial. As ações coletivas sinalizaram que os idosos reconheceram as modificações causadas pela velhice, mas estas, não impediram de participarem do grupo independente da sua autoestima, fortalecendo o processo de empoderamento. Conclusão: destacou-se a preocupação da beleza e aparência como representações corporais impostas pela sociedade, mesmo com as marcas naturais do envelhecimento, os idosos sentem-se satisfeitos com sua imagem corporal.

Descritores: Idoso; Saúde do Idoso; Promoção da Saúde.

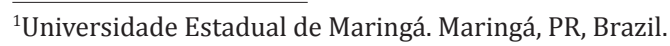

Corresponding author: Raquel Cristina Luis Mincoff.

Rua Pioneiro Mário Buralli, 458. CEP: 87053-268. Maringá, PR, Brazil. E-mail: raquel.mincoff@gmail.com 


\section{Introduction}

The technological advances in the health area, associated to the increase in longevity and health literacy, are possible factors responsible for the increase in life expectancy ${ }^{(1)}$. Similar to the world scenario, the aging Brazilian population is estimated at around 17.6 million $^{(1)}$ with representative projections up to the year 2050, passing to the sixth oldest population in the world ${ }^{(2)}$.

With aging, bio psychosocial changes can lead to a decrease in people's ability to adapt to the environment, with a tendency towards greater vulnerability and health problems ${ }^{(3)}$. In this process, the perception of the elderly in relation to their body image is an important determinant ${ }^{(4)}$, which corroborates the coping of the changes in life intercourse, favoring healthy aging.

It is essential to know the changes and influences of self-image in the life of the elderly ${ }^{(3)}$, especially considering that self-knowledge allows self-esteem, anchored in values, life stories, self-confidence and self-respect. It represents, therefore, the reinforcement of resilience and mutual protection skills as strategies of self-management by the community itself according to its own needs ${ }^{(5-6)}$.

Considering that empowerment implies conquest, advancement and overcoming by the one that empowers, the elderly person, group or institution with these characteristics is the one that performs change and actions on their own, attitudes that strengthen and instigate to produce health in the guarantee of improvement in quality of life ${ }^{(7-8)}$. Self-image, as an elderly person's mental representation of his own body, can influence his state of health ${ }^{(9)}$ and is an important component of empowerment and autonomy.

Aging well is a constant search for the elderly, reinventing old age as a time of transformation and pleasure, agents of change ${ }^{(10)}$, for which community spaces that facilitate socialization collaborate greatly. Regarding the social encounter of peers, the productive aspects of leisure ${ }^{(11-12)}$ have occupied a prominent place with positive consequences for concrete situations of self-knowledge, autonomy, empowerment and emancipation, with the elderly groups being one of these means.

For this reason, the study was justified by being involved with a demand that emerged in the bond with the group, demonstrating its social relevance and practical application. In addition, it was interesting to know how self-image can be identified and dialogued for awareness, lacking studies that show this relationship.

For the present study the following study questions were formulated: What is the meaning of self-image that prevails in the elderly group? To what extent can the dialogue on body image constitute a strategy that favors the process of emancipation of knowledge and empowerment? In view of this, the objective was to understand dialogues about body image with the elderly in Primary Health Care.

\section{Methods}

It was an action research ${ }^{(7,13)}$ developed during the month of June 2017 during the accomplishment of a group of coexistence existing five years ago, in a Basic Health Unit whose scenario integrates actions in partnership with an institution of higher education for two years, located in the municipality of Maringá-PR, Brazil.

Fifteen elderly people from the 20 members of the coexistence group linked to the aforementioned unit, entitled "De Bem com a Vida", participated in the study. The groups took place weekly and were held in 23 meetings with the performance of activities permeated by social leisure, under the coordination and execution of professionals of the service and the academy. The activity that originated this study was carried out in a meeting, centered on the subject of self-image.

Two strategies were used to collect the data: group discussion mediated by the photo-elucidation technique $^{(14)}$ and workshop, with emancipatory cha- 
$\operatorname{racter}^{(7,15)}$. The photo-elucidation allowed establishing the perceptions of the elderly regarding body image, interpreted and reinforced by the emancipatory workshop, based on a free, critical and reflexive discussion about the body image in aging and its influences on the freedom of expression of sexuality in daily life of these elderly people.

To develop the photo-elucidation and start the dialogues, images previously selected by the researchers were presented to the group as a discussion and reflection trigger. These portrayed the image of a baby, a child, a teenager, a young man, an adult and an elderly man, followed by the following question: in your perception, which of these images represents beauty?

After the photo-elucidation, for the problematization of the self-image by the elderly, the emancipatory workshop was triggered by the following triggering questions: Do you consider that the elderly are satisfied with their body? To what extent do the elderly care about their appearance? How do you demonstrate this concern (or lack of concern)? Does our society recognize beauty in the elderly? Why?

The discussions generated by the photo-elucidation and the emancipatory workshop were recorded in audio, using a cellular phone as equipment, and later transcribed in full by the researchers.

The transcripts of the photo-elucidation and the emancipatory workshop were organized in a textual corpus, referring to the experiences of the elderly in relation to the satisfaction or not with body image, and processed using the software Interface de $\mathrm{R}$ pour les Analyses Multidimensionnelles de Textes et de Questionnaires (IRaMuTeQ®), which enables different processing and statistical analysis of produced texts $^{(16)}$.

For this study, we used the Descending Hierarchical Classification, which is the mechanism that makes up the software and consists of the use of the corpus for the dimensioning of text segments in Elementary Context Units, classified according to the most frequent vocabularies present in each class, having in order to understand that they are significant for the qualitative analysis of the data. The words were organized by a dendogram that represented the quantity and lexical composition of classes from a grouping of terms, from which the absolute frequency of each was obtained ${ }^{(16)}$.

The findings were interpreted and discussed in the light of critical-educational pedagogy ${ }^{(7-8)}$, centered on the oppressive image of the people and the search for freedom by the problematization that makes it possible to modify concepts and attitudes by strengthening the autonomy and emancipation conquered along with their peers.

To ensure the anonymity of the participants, the reports from the discussions generated by the photo-elucidation and emancipatory workshop were identified with the letter " $\mathrm{P}$ ", referring to the term Participant, followed by Arabic numerals that corresponded to each elder from the sequence of the group speeches.

The study was approved by the Ethics Committee in Research involving human beings of the State University of Maringá (no 37457414,6,0000,0104, opinion no $1,954,350 / 2017$ ).

\section{Results}

Regarding the characterization of study participants, all 15 elderly were female and the age range was from 60 to 91 years. Regarding the time of participation in the coexistence group, there was a variation from two months to three years.

The Descending Hierarchical Classification allowed the analysis of 95 text segments, 60 texts (63.1\%) were used and 3,193 word occurrences were identified. A lexical class (class 1) emerged with the presentation of two subclasses (classes 2 and 3), which illustrates the interclasses relationship, as demonstrated by the clouds of words present in the classification dendogram (Figure 1), which can be interpreted. 


\begin{tabular}{|c|c|c|}
\hline Class 1: 43,3 & Class 3: $33,3 \%$ & Class $2: 23,3 \%$ \\
\hline Today & Find & Money \\
\hline Day & To like & Because \\
\hline Year & God & Old age \\
\hline Already & Clothing & To respect \\
\hline Way & Taste & Old \\
\hline Pass & Shorts & men \\
\hline Age & Turn & Understand \\
\hline So & Bad & Place \\
\hline Now & To give & Ungrateful \\
\hline Straighten & Wear & Gray \\
\hline House & Leg & also \\
\hline More & Show & pretty \\
\hline Son & I enjoy & Very \\
\hline Service & Good & Not \\
\hline Anything & Speak & Up until \\
\hline Create & Leave & Girl \\
\hline Begin & Only & There \\
\hline New & On here & Take \\
\hline Come over & Like this & Board \\
\hline Take along & To feel & Head \\
\hline Letter & Sir & Old man \\
\hline People & Marry & When \\
\hline Kid & Stay & Stay \\
\hline Take care & All & Medicine \\
\hline Thing & Want & Woman \\
\hline Нарру & Negotiate & Negotiate \\
\hline Grow up & & \\
\hline Dad & & \\
\hline
\end{tabular}

Figure 1 - Dendogram: experiences of the elderly of the coexistence group in relation to satisfaction or not with body image

For the clarity of the three classes, their semantic organization and lexicographic analysis, the interpretation of the findings was systematized considering the highlighted words. It can be observed that in Figure 1 the words are randomly positioned, the most frequent ones appear larger than the others, evidencing their prominence in the corpus of the research analysis.

In Class 1 (Elementary Context Unit=43.3\%) the word today $(n=15)$ was the one with the highest frequency, followed by the word day $(\mathrm{n}=11)$ and year $(n=9)$. The interpretation that has been made regarding the meanings of words is the relevant concern that beauty assumes in the present day, exemplified in the following lines: The majority of the elderly today is concerned with the appearance. Most are beautiful. They expose what they feel, wander, it is the best age (P1). You have to try to look beautiful every day, get up early, put a cream on your face, and comb your hair well, if you think it is beautiful. Put a lip gloss on your mouth (P2). I live in an apartment, so I have to get downstairs to be neat, I cannot leave anyway. What if someone finds me? If you look at me from the top down, I'm already depressed. The appearance of the people is linked in the social presence (P3).

The experiences about the perception of the body image by the elderly were evidenced in Subclass 3 (Elementary Context Unit $=33.3 \%$ ) from the words find $(n=8)$, like $(n=7)$ and God $(n=6)$, related to the concerns about the appearance and the corporal representation imposed by the society, as observed in the participatory discussions: I had a breast cancer and my hair is beginning to grow again. It may be white, rolled up; anyway, I'm going to value more today, before I could not see my hair. Sometimes people say that my hair is bad, but I like my hair, I think we have to like everything we have. It was God who made us so (P3). I lost weight a little. When I see myself facing the mirror, I see so much that it displeases. You are accustomed to that beautiful body; you grow old and cannot understand why old age is 
so ungrateful. I'm with what God gave me. I think the ideal clothing is the one that you feel good about (P1). When we were young, the parents would not wear a lowered skirt, could not show their legs, their thighs. I married, and he only had anger when I talked about cutting hair, but everything my husband took care of, and he liked long hair. This shirt I'm wearing, the granddaughter made me put (P4).

In this way, what the old person thinks of his body is in line with what is perceived socially. The perception of beauty is based on the expression, interpretation and unique personal experiences, but influenced by the culture and, therefore, the elderly associates the beautiful to the childhood and to the youth, as presented in the lines: There is a little baby. They have the children, the children. The young couple. All are beautiful, but the baby is more (P1). The baby represents beauty. The children. I think the children (beautiful), because there is hope there (P2).

When the participants were asked if the society recognizes the beauty of the elderly person, the reports indicate that the elderly to be considered beautiful are those with high financial condition, reason for the word money $(n=6)$ to be highlighted in Subclass 2 Context Elementary $=23.3 \%$ ), marking the commercialization of beauty: When you are old with money, make a liposuction, put a little something here, there. When you do not have the money, it's difficult, because you have to go to a hairdresser's, you have to dye your hair and otherwise you get old woman's hair (P3). Not man, man is handsome gray, and woman is relaxed, others talk. Then you want to do a nail, and you have no money, because you have to buy the medicine, you have it too. We have to fight every day for better (P7).

Another clear disclosure was due to the disrespect to the elders, therefore, the frequency of the word respect $(n=5)$. The word oldness $(n=4)$, although with less prominence and, given the characteristics of aging, meant a positive period, with experiences and experiences built throughout life, so that the elderly are satisfied with their current body image: Some recognize others do not. Most do not. We have to do something to be seen. People do not see, do not respect. And especially those at home. The ones at home are worse (P15). Even with old age, I am satisfied the way I am by the age I have (P8). Be good to yourself. Being a really nice person, talking to everyone, feeling good. You have to be well with you to feel beautiful. And well with you to talk to people too, smiling inside (P10).

It should be clarified that the discussions that followed in the workshop were consistent with a new understanding of beauty and body image: I am concerned with appearance, zeal for my well-being, I feed myself well, I do my best and the impossible to be well, alone I get knocked over when I'm sick (P6). This is the representation of joy. For this woman, she does not have a bad day, she is eighty-three, she is studying, she is beautiful and so she is happy (P13). You have to feel good. I wear what I like. I feel beautiful, beautiful and cheerful. I'm fine with myself. I'm a very nice person, I talk to everybody and I feel good. You have to be well with you to feel beautiful (P2).

\section{Discussion}

The limitation of the study was the realization of only one meeting that approached the presented theme, making it difficult to evaluate new perceptions. In addition, some elderly individuals presented weaknesses in the effective understanding of the investigated one, which may interfere in the quality of the answers. These limitations allow further investigation.

In this research, the body image presented in the participants' lexicon reflects the essential element under a new perspective of beauty, which fits the body image tied to successful old age. Thus, it can be redefined not by comparison to younger individuals, but by preserving the individual's potential for development $^{(17)}$.

Such aspects corroborate the liberating character of Freire's critical pedagogy, which remains current on the claim that removing the subject from consciousness and removing his right to transform the world is oppressive. Achieving authentically liberating education requires conscious action by people to transform reality ${ }^{(7-8)}$.

Healthy aging, therefore, should be an association between physical and mental health, independence and autonomy in daily activities, integration and social inclusion, family support and economic 
independence ${ }^{(17)}$, for which body image collaborates greatly. The speeches portrayed the relevance of the healthy and balanced self-image of the elderly in the social community, which is why they are too preoccupied with their personal appearance.

The inclusion in collective and community activities in Primary Health Care allows spaces to demystify the values and meanings of body image in the daily life of the elderly. Freire believed in the possibility of change concerning the human being as unfinished subjects and in their awareness of their situation of exploitation and domination in the face of society's followings ${ }^{(7-8)}$.

Satisfaction with self-image is related to social engagement and is related to emancipation, through the dissemination of information and education, as a basis for decision-making. For this reason, the empowerment process is possible by the group organization, based on the changes related to acceptance and personal satisfaction ${ }^{(17)}$.

Another related issue is that there is a combination between the representations of age-related changes and the distorted views of older people, aspects that depreciate aging ${ }^{(17)}$. In this direction, it should be noted that there was no one who chose the image of the elderly as a synonym of beauty. Chronological age and the visible marks of time seem to be decisive for measuring, establishing beauty, and classifying young and old. The social representation of the elderly is very widespread in western culture, which in no way allows us to renew ideals that facilitate an alternative of beauty, value the experience and even consider the relevance of the elderly to the socialization of the younger people ${ }^{(18)}$.

The perceptions of aging reflected in the workshop constituted a combination between representative changes of reality, with distorted visions and related to the jovial stereotype, and this may be one of the reasons that the elderly view beauty in children's portraits ${ }^{(18)}$, as this study has learned.

The pressure that society imposes on the be- auty model can influence all generations, with greater oppression of the elderly population, who must adapt to the new characteristics inherent to aging, without the joviality of the body, which can reinforce an unsatisfactory self-image $\mathrm{e}^{(18-19)}$.

In this sense, Freire's thought contributes to an education aimed at liberating the subject from the dominant moorings in society, to the right to freedom and equality, so that the elderly can develop a conscious critical understanding of their relation with the world $^{(7-8)}$, as done in the emancipatory workshops.

Knowing that satisfaction with body image can determine the capacity of people in their own initiatives $^{(5)}$, dissatisfaction produces an opposite result and weakens the process of empowerment. For this reason, bringing the subject body image to dialog spaces, as in this study, can reshape concepts and practices ${ }^{(6)}$.

Liberating educational strategies, also called emancipatory, such as liberating education ${ }^{(7-8)}$, because of its critical and educational face, can serve as a relevant instrument against the oppression of the body image that this work evidenced and developed as it followed in the presentation of the findings.

As for the strengthening of older people's safety in their image, they recognize the changes caused by old age, but these did not prevent them from feeling resolute, daring and even courageous, denoting the decision-making power to participate in the group independent of his self-image.

Adopting these modifications allows us to forget the accumulated experiences; the years lived, adding beauty to life and to the body itself by signaling its existence ${ }^{(18)}$. The educational practice proposed by Freire supposes that accepting oneself is to develop a conscious critical understanding of their relationship with the world, to become more aware of their context and their condition as a human being ${ }^{(7)}$.

Dialogue is part of the history of the development of human consciousness, since it is the moment when human beings meet to reflect on reality, because it entails an active reflection on other human beings, it 
is fundamentally social, requiring a critical thinking ${ }^{(7)}$.

Social and family influences are pertinent in the phases of life, especially with regard to the way of acting and thinking, sometimes establishing oppressive roles that interfere in the bio psychosocial changes of aging. It is relevant to encourage the construction of the body image through self-discovery and self-concept discussed in family life, in social groups, understanding the opposite idea of oppression, that is, of emancipatory transformation ${ }^{(17)}$.

The emancipation of knowledge by elderly people who socialize in groups strengthens the link between the health services, becomes a potential tool for improving the quality of life and a constant search for social transformation ${ }^{(13)}$. The Freire's reflection dialogues with the individual who is not afraid to face, not to hear, that is, he is not afraid to reveal the world. This dialogue results in increasing knowledge of both ${ }^{(7)}$.

Thus, promoting health is substantial, it enables the empowerment of people so that they can make healthier choices of life and, thereby, strengthen the actions necessary for a better quality life ${ }^{(17)}$. Thus, each individual must identify their needs and take responsibility for their own care, acquire the ability to emancipate themselves, such skill portrayed by notes in the reports said by the elderly.

\section{Conclusion}

The research fulfilled its role of reordering concepts and perspectives about the body image, emphasizing the concern of beauty and appearance as corporal representations imposed by the society. The model of beauty standardized in contemporary reality imposes the perfect body and rejuvenation as acceptable, which can cause rejection and mismatch to the natural process of aging. Despite the natural marks, the elderly do not intimidate themselves, dress and act pleasantly in the intention of feeling satisfied with their body image.

\section{Acknowledgements}

To the Coordenação de Aperfeiçoamento de Pessoal de Nível Superior and to the Instituto Cesumar de Ciência, Tecnologia e Inovação do Centro de Ensino Superior de Maringá for the promotion of the research grant.

\section{Collaborations}

Silva PA and Lourenço MP contributed to the design, analysis and interpretation of data and writing of the article. Nogueira IS e Mincoff RCL collaborated with writing the article and the relevant critical revision of the intellectual content. Baldissera VDA contributed to the writing of the article and relevant critical revision of the intellectual content. All authors contributed to the approval of the final version to be published.

\section{References}

1. GuimarãesJS, LimaAP, Cardoso FB. Efeito da prática do Tai Chi Chuan na autoestima e autoimagem de idosos. Rev Bras Prescriç Fisiol Exerc [Internet]. 2018 [citado 2018 set. 13];11(71):952-9. Disponível em: http://www.rbpfex.com.br/index. php/rbpfex/article/view/1317/1005

2. United Nations Development Programme. Human Development report 2015: work for human development [Internet]. 2015 [cited Sep 13, 2018]. Available from: hdr.undp.org/sites/default/ files/2015_human_development_report.pdf

3. Costa FRD, Rodrigues FM, Prudente COM, Souza IFD. Quality of life of participants and nonparticipants of public physical exercise programs. Rev Bras Geriatr Gerontol. 2018; 21(1):24-34. doi: dx.doi.org/10.1590/1981-22562018021.170136

4. Ferreira AA, Menezes MFG, Tavares EL, Nunes NC, Souza FP, Albuquerque NAF, et al. Estado nutricional e autopercepção da imagem corporal de idosas de uma Universidade Aberta da Terceira Idade. Rev Bras Geriatr Gerontol. 2014; 17(2):289-301. doi: http://dx.doi.org/10.1590/ S1809-98232014000200007 
5. Jesus MBC, Bomfim MRB, Santos ICVS, Martins MF, Aleluia IRS, Ribeiro NA, et al. O impacto de atividades coletivas na capacidade funcional em idosos. Rev Saúde Com. 2017; 13(2):894-901. doi: http://dx.doi.org/10.22481/rsc.v13i2.439

6. Fonseca CC, Chaves ECL, Pereira SS, Barp M, Moreira AM, Nogueira DA. Autoestima e satisfação corporal em idosas praticantes e não praticantes de atividades corporais. Rev Educ Fis UEM. 2014; 25(3):429-39. doi: http://dx.doi.org/10.4025/ reveducfis.v25i3.22050

7. Freire P. Pedagogia do oprimido. Rio de Janeiro: Paz e Terra; 2018.

8. Freire P. Pedagogia da autonomia: saberes necessários à prática educativa. Rio de Janeiro: Paz e Terra; 2017.

9. Valença TDC, Santos WS, Lima PV, Santana ES, Reis LA. Physical disability in old age: a structural study of social representations. Esc Anna Nery. 2017; 21(1):e20170008. doi: http://dx.doi. org/10.5935/1414-8145.20170008

10. Dabove MI. Derechos humanos de las personas mayores en la nueva Convención Americana y sus implicancias bioéticas. Rev Latino-am Bioética. 2016; 16(1):38-59. doi: http://dx.doi. org/10.18359/rlbi.1440

11. Moura MMDD, Veras RP. Acompanhamento do envelhecimento humano em centro de convivência. Physis Rev Saúde Coletiva. 2017; 27(1):19-39. doi: dx.doi.org/10.1590/s0103-73312017000100002

12. Wetzel M, Huxhold O. Are leisure activity and health interconnected after retirement: educational differences. Advances Life Course Res. 2016; 30:43-52. doi: https://doi.org/10.1016/j. alcr.2016.03.007

13. Oliveira E, Soares CB, Silva JA. Emancipatory action research with young schoolchildren: experience report. Rev Gaúcha Enferm. 2016; 37(3):e62059. doi: dx.doi.org/10.1590/19831447.2016.03.62059
14. Cortés AIR. Desenhos, vinhetas e diagramas: ouvindo as narrativas das crianças através da elucidação gráfica. Rev Pesq Qual [Internet]. 2017 [citado 2018 set. 13]; 5(8):312-26. Disponível em: https://www.researchgate.net/ publication/318378659/download

15. Oliveira E, Souza GC, Soares CB. Pesquisa-ação: oficinas emancipatórias como instrumento para coleta de dados e apreensão das representações cotidianas. Rev Sociol Rede [Internet]. 2015 [citado 2018 set. 13]; 5(5):12-26. Disponível em: http://redelp.net/revistas/index.php/rsr/ article/view/2soares5

16. Ferreira ACP, Araújo EC, Abreu PD, Vasconcelos LMR, Valença KSL, Santana MÊS. Family assessment of transsexual women with HIV/ AIDS in the light of the Calgary Model. Rev Enferm UFPE on line [Internet]. 2018 [cited Sep 13, 2018];12(3):801-4. Available from: https:// periodicos.ufpe.br/revistas/revistaenfermagem/ article/view/234405/28049

17. Lopes MA, Krug RR, Bonetti A, Mazo GZ. Envelhecendo na percepção das pessoas longevas ativas e inativas fisicamente. Estud Interdiscip Envelhec [Internet]. 2014 [citado 2018 set. 13]; 19(1):141-53. Disponível em: http://seer. ufrgs.br/index.php/RevEnvelhecer/article/ view/40524

18. Garbaccio JL, Tonaco LAB, Estêvão WG, Barcelos BJ. Aging and quality of life of elderly people in rural areas. Rev Bras Enferm. 2018; 71(Suppl 2):724-32. doi: http://dx.doi.org/10.1590/00347167-2017-0149

19. Frazão MCLO, Pimenta CJL, Silva CRR, Vicente MC, Costa TF, Costa KNFM. Resiliência e capacidade funcional de pessoas idosas com diabetes. Rev Rene. 2018; 19:e3323. doi: http://dx.doi. org/10.15253/2175-6783.2018193323 